\section{BRACHYSTELMA NALLAMALAYANA SP. NOV. (APOCYNACEAE: ASCLEPIADOIDEAE: CEROPEGIEAE) FROM INDIA}

\section{Kothareddy Prasad ${ }^{1} \&$ Boyina Ravi Prasad Rao ${ }^{2}$}

1,2 Biodiversity Conservation Division, Department of Botany, Sri Krishnadevaraya University, Anantapur, Andhra Pradesh 515003, India ${ }^{2}$ Member, Indian Subcontinent Plant Specialist Group, Species Survival Commission IUCN, Biodiversity Conservation Division, Department of Botany, Sri Krishnadevaraya University, Anantapur, Andhra Pradesh 515003, India ${ }^{1}$ prasad.orchids@gmail.com, ${ }^{2}$ biodiversityravi@gmail.com (corresponding author)

The genus Brachystelma R. Br. (Apocynaceae, Asclepiadoideae, Ceropegieae) has about 120 species widely distributed in South Africa, South-east Asia and Australasia (Meve 2002). In India it is represented by 18 species (Karthikeyan et al. 2009; Rao et al. 2011). During floristic explorations in the Nallamalai Hill ranges of Andhra Pradesh, the authors have collected curious specimens of Brachystelma, which after critical examination were found to be novel. A perusal of the literature revealed that these specimens are allied to Brachystelma maculatum Hook.f.

Materials and Methods: The material for the present study is based on recent collections by the authors from Bheemunikolanu area, from near Srisailam in the Nallamalai Hill ranges of Andhra Pradesh. The specimens used in this study are deposited at SKU (Sri Krishnadevaraya University, Andhra Pradesh).

\section{Brachystelma nallamalayana \\ sp. nov.}

(Fig. 1 \& Images 1 \& 2)

Material examined: Holotype: SKU 34667, Isotypes BSID, 31.vii.2010, $16^{\circ} 02^{\prime} N$ \& $98^{\circ} 55^{\prime} E$, elevation 560m, Bheemunikolanu Hills (Nallamalais, Eastern Ghats), Andhra Pradesh, India, Coll. Rao \& Prasad.

Diagnosis: Brachystelma nallamalayana sp. nov. is distinguishable from Brachystelma maculatum by the following characters: longer stems, peduncled cymes, basally united calyx lobes and biseriate corona.

Description: Erect herbs, up to $80 \mathrm{~cm}$ high. Roots tuberous, in varied shapes, generally fusiform, to $6 \times 3 \mathrm{~cm}$ diam., brownish. Stem solitary, terete, 1-2 mm in diam., unbranched, ridged, succulent, glabrous, glaucous green; internodes up to $10 \mathrm{~cm}$ long. Leaves simple, opposite, decussate, fleshy, sessile; lamina linear, up to $19 \mathrm{~cm}$ long and ca. $2 \mathrm{~mm}$ diam., acute at apex, undulate along margins, glabrous, sometimes hairy on the mid vein. Inflorescence crowded at apical nodes, lateral, shortly peduncled, umbellate, 5-6 flowered, pendulous; pedicels terete, filiform, up to $1.3 \mathrm{~cm}$ long, glabrous. Bracts and bracteoles persistent, linear, acute at apex, glabrous, greenish-pink; bracts $2 \times 0.5 \mathrm{~mm}$; bracteoles $1 \times 0.2 \mathrm{~mm}$. Calyx 5-lobed, united at base; lobes linear, $3 \times 0.5 \mathrm{~mm}$, acute at apex, 3-5 veined, glabrous, pinkishgreen. Corolla 5-lobed; corolla tube up to $1 \mathrm{~mm}$ long, shallow; corolla lobes erect, linear, 5-9x2 mm diam., acute but appears obtuse due to inturned apex, faintly 5-veined, margins involute with 1-2 mm long pink hairs

DOI: http://dx.doi.org/10.11609/JoTT.03533.4904-6

Editor: N.P. Balakrishnan, Retd. Botanical Survey of India, Coimbatore, India.

Date of publication: 26 October 2013 (online \& print)

Manuscript details: Ms \# 03533 | Received 16 February 2013 | Final received 10 October 2013 | Finally accepted 12 October 2013

Citation: Prasad, K. \& B.R.P. Rao (2013). Brachystelma nallamalayana sp. nov. (Apocynaceae: Asclepiadoideae: Ceropegieae) from India. Journal of Threatened Taxa 5(14): 4904-4906; http://dx.doi.org/10.11609/JoTT.03533.4904-6

Copyright: (C) Prasad \& Rao 2013. Creative Commons Attribution 3.0 Unported License. JoTT allows unrestricted use of this article in any medium, reproduction and distribution by providing adequate credit to the authors and the source of publication.

Funding: The present study was conducted with the financial support from Department of Biotechnology, Government of India, New Delhi (BT/PR12654/ NDB/52/146/2009)

Competing Interest: Authors declare no competing interests.

Acknowledgements: The authors are also grateful to Dr. P. Tetali, Naoroji Godrej Centre for Plant Research, Pune; Dr. David J. Goyder, Royal Botanic Gardens, Kew; Dr. Ulrich Meve, University of Bayreuth, Germany and Prof. M.K. Janarthanam, Goa University for giving valuable comments. We thank the authorities of Botanical Survey of India, Kolkata for providing relevant literature. 

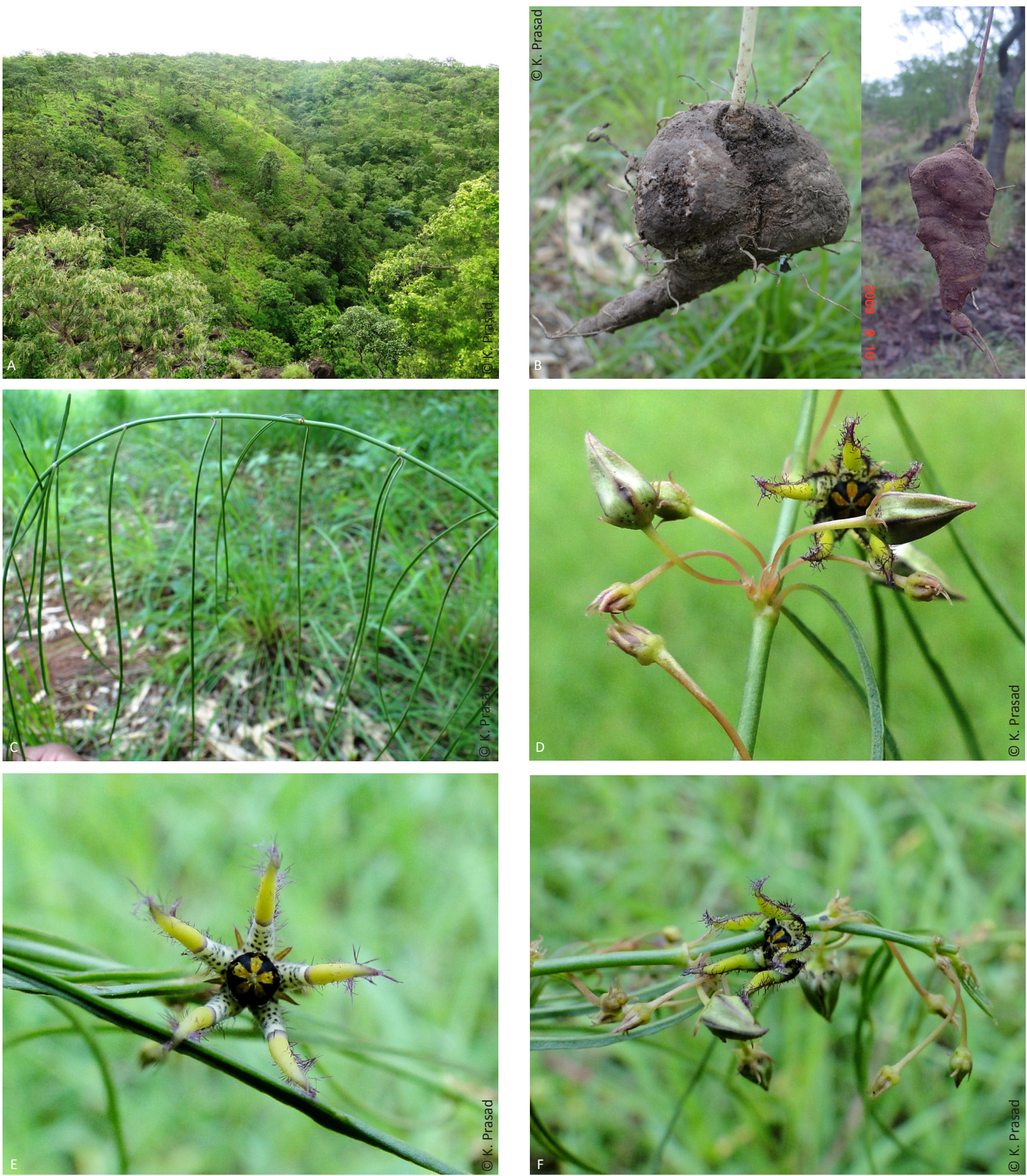

Image 1. Brachystelma nallamalayana sp. nov.

A - habitat; B - tubers; C - leaves; D - inflorescence; E \& F - flowers.

throughout, more dense at apex; lobes basally pale white with black spots and yellow above without any blotches. Corona ca. $3 \mathrm{~mm}$ across, biseriate, glabrous; interstaminal corona obscurely 5-angled, cupular, forms a continuous ring around the gynostegium, brown; staminal corona 5-lobed, black; lobes appressed to the back of the anthers, exceeding and hooded on the style apex. Pollinia waxy, yellow, globose, ca. $200 \mu \mathrm{m}$ long, margins pellucid at apex, attached by light brown tubular caudicles to a red-coloured corpuscle. Style apex pentangular. Follicles not seen.

Flowering: July-August. 


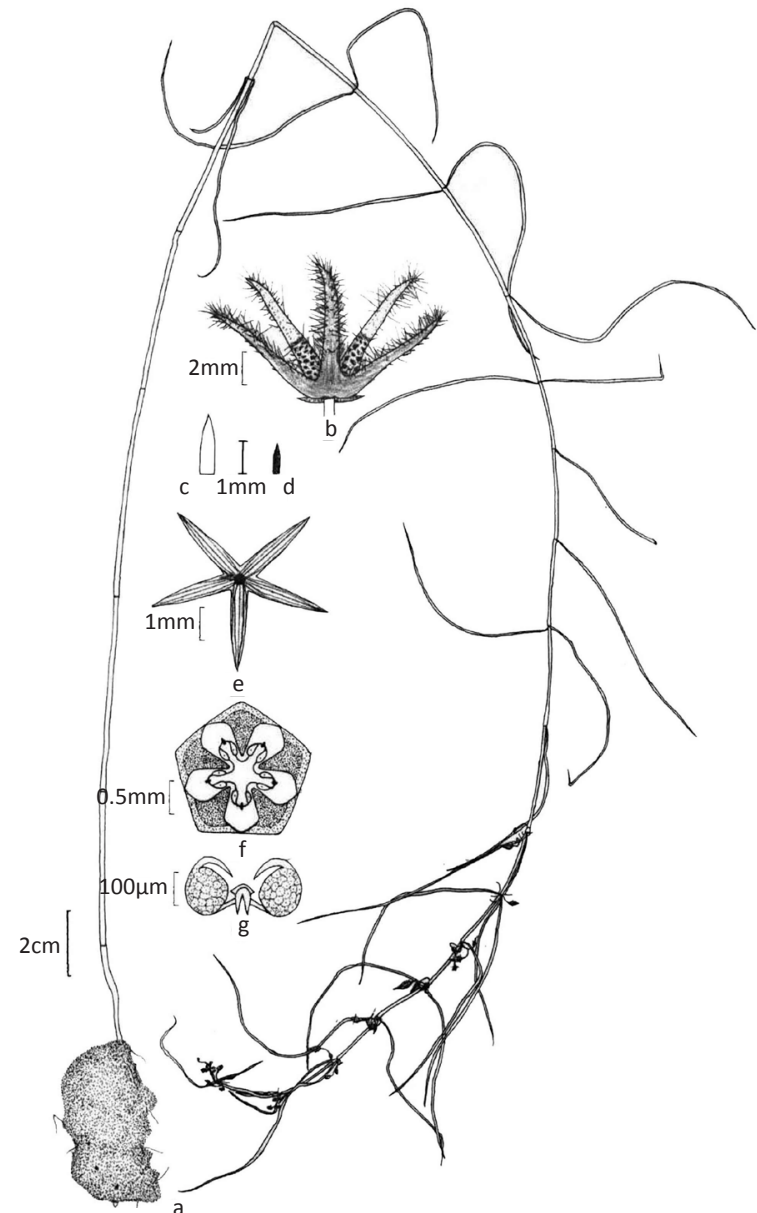

Figure 1. Brachystelma nallamalayana sp. nov.

a - habit; b - flower; c - bract; $d$ - bracteole; e - calyx; f - corona top view; g - pollinia

Etymology: The new species is named after the type locality, the Nallamalais of Andhra Pradesh, India.

Habitat and Distribution: This species occurs amidst grasses on open hill slopes of dry deciduous forests at an altitude between 550-600 m, associated with Cymbopogon coloratus and Heteropogon contortus.

Discussion: The new species Brachystelma nallamalayana is similar to $B$. maculatum but differs in having longer stems (ca. $80 \mathrm{~cm}$ long) peduncled cymes, basally united calyx lobes and biseriate corona (vs. shorter ca. $30 \mathrm{~cm}$ long stems, sessile cymes, basally free calyx lobes and uniseriate corona in B. maculatum).

Conservation status: The new species of Brachystelma nallamalayana Prasad and Ravi Prasad Rao has restricted distribution and currently is known only from type locality in an area about $10 \mathrm{~m}^{2}$ and represented by about 60 individuals. Until further explorations determine

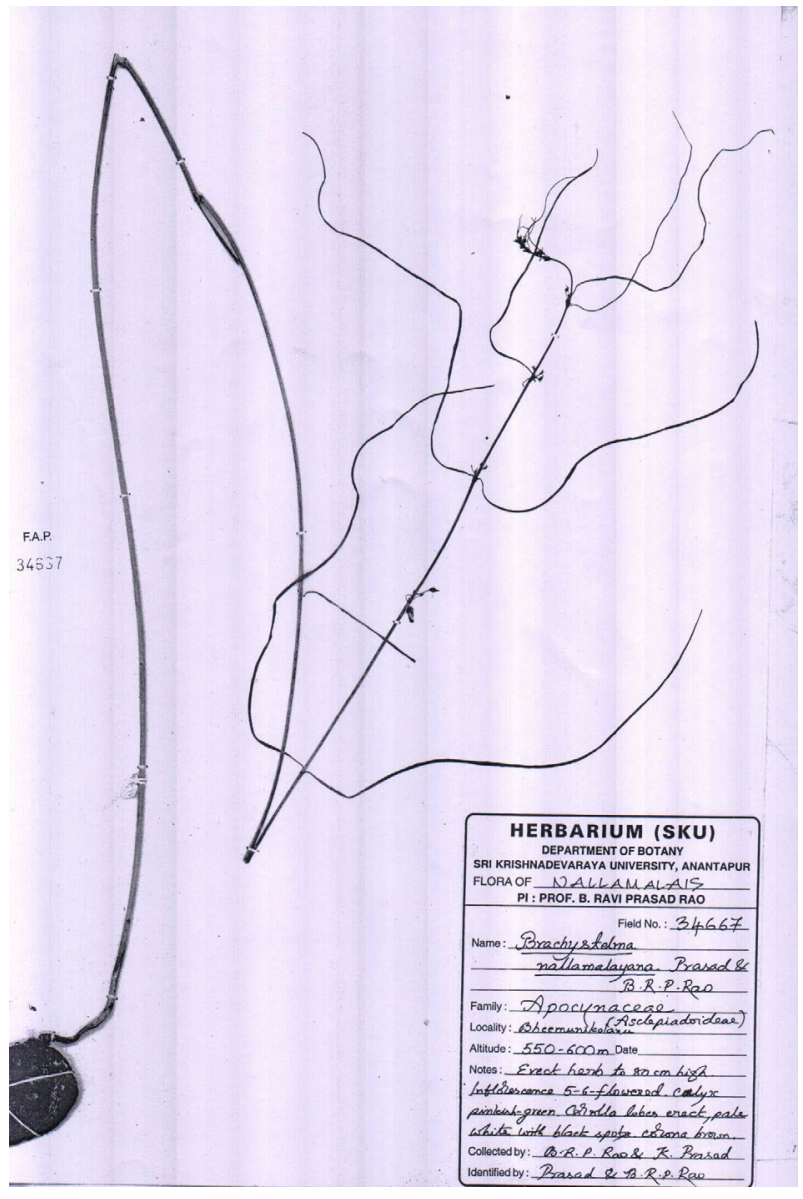

Image 2. Herbariuam specimen

its distribution range, biology and threats, the species cannot be assessed. While the available information perhaps qualifies it initially as a Critically Endangered species, it is at present Data Deficient.

\section{REFERENCES}

Karthikeyan, S., M. Sanjappa \& S. Moorthy (2009). Flowering Plants of India: Dicotyledons.Vol. 1. (Acanthaceae - Avicenniaceae). Botanical Survey of India, Kolkata.

Meve, U. (2002). Brachystelma, pp. 20-46. In: Albers, F. \& U. Meve (eds.). illustrated Handbook of Succulent Plants: Asclepiadaceae. Spinger-Verlag, New York, 321pp; http://dx.doi.org/10.1007/978-3642-56370-6

Rao, B.R.P., K. Prasad, B. Sadasivaiah, S.K. Basha, M.V.S. Babu \& P.V. Prasanna (2011). A new species of Brachystelma R. Br. (Apocynaceae: Asclepiadoideae - Ceropegieae) from India. Taiwania 56(3): 223-226. 